\title{
Stabilita barevné vrstvy akvarelu v podmínkách umělého stárnutí
}

\section{Stability of the aquarelle paint layer in the artificial aging conditions}

\author{
Ohlidalová M. ${ }^{1}$, Krejčová D. ${ }^{l}$, Dytrychová E. ${ }^{1}$, Paulusová $H .{ }^{2}$, Hostašová A. ${ }^{3}$ \\ ${ }^{1}$ Univerzita Pardubice, Fakulta restaurování \\ ${ }^{2}$ Národní archiv, Oddělení péče o fyzický stav archiválií \\ ${ }^{3}$ VŠCHT Praha, Ústav chemické technologie restaurování památek \\ E-mail: martina.ohlidalova@upce.cz
}

Barevné vrstvy uměleckých děl stejně jako všechny materiály jsou rovněž prededmětem přirozeného stárnutí. Vliv vnějšich faktorů na tyto vrstevnaté systémy uměleckých děl ale dosud nebyl systematicky studován. Hlavním cílem této práce bylo sledováni chování akvarelì, jako vybraného zástupce maliřrské techniky na papíre, v podminkách umélého stárnutí běžně použivaných při studiu degradace papiru (umělé stárnutí v prítomnosti $\mathrm{NO}_{2}$, umělé stárnutí vlhkým teplem a termické stárnuti). Testovány byly vzorky akvarelü na ručním papiře a dřevitém balicím papíre pripravené z pigmentu (pruská modr̆, francouzský okr, ultramarin, brazilské drevo a řešetlák) a arabské gumy. U pripravených vzorku akvareli byly po expozici podmínkám umělého stárnutí vyhodnoceny změny jejich optických vlastností (celková barevná diference, UV-VIS reflexní křivky, elektronová mikroskopie) a chemického složení (změny hodnot pH, rentgenová difrakčni analýza, ATR-FTIR spektroskopie a Ramanova spektroskopie). Významné změny byly detekovány ve vzorcich akvarelů s pigmentem měděnka vi̊či všem testovaným podminkám umělého stárnutí souvisejici s detekovanými změnami chemického složení. Experimentálně byl také prokázán významný vliv atmosféry $\mathrm{NO}_{2}$ u vzorků akvarelu s organickými laky.

\section{ÚVOD}

Chemická povaha barevných vrstev malírských děl je velmi důležitá $z$ pohledu jejich celkové stability a následné ochrany. $\mathrm{K}$ řešení problémů spojených s jejich degradací a bezpečnému použití konzervačních metod (např. dezinfekci či odkyselování) není možné přistoupit bez pochopení jejich chování. Negativní působení vnějších vlivů (nečistoty ovzduší, teploty či relativní vlhkosti prostředí) na stabilitu materiálů předmětů kulturního dědictví je obecně znám a široce studován. Jejich vliv na vrstevnaté systémy barevných vrstev uměleckých děl je ale předmětem zájmu pouze ojediněle, např. [1,2]. Nejčastější metodou pro předpovídání chování materiálů po delším časovém období je
As all materials, paintings' paint layers succumb to natural aging. The impact of external factors on these layered systems has never been studied systematically. The main goal of this paper was to study behaviour of aquarelles as a selected representative of a technique of painting on paper under the conditions of artificial aging usually used in paper degradation studies (artificial aging in the presence of $\mathrm{NO}_{2}$, artificial aging by humid heat and thermal aging). Samples of aquarelles on a hand-made paper and on wood kraft paper made from pigments (Prussian blue, French ochre, ultramarine, Brazilian wood and buckthorn) and gum Arabic. After the exposure to the conditions of artificial aging, the prepared samples were reported to have changed in terms of their optical properties (the general colour differentiation, UV-VIS reflex curves, electron microscopy) and chemical composition (changes in $\mathrm{pH}, \mathrm{x}$-ray diffraction analysis, ATR-FTIR spectroscopy and Raman spectroscopy). Substantial changes were detected in the aquarelle samples containing verdigris pigment at all tested conditions of artificial aging associated with the detected changes of chemical composition. Significant impact of $\mathrm{NO}_{2}$ atmosphere on aquarelle samples with organic varnishes were experimentally proved, too.

umělé stárnutí modelových vzorků, které může poskytnout informace o jejich chování a vytvořit základ pro preventivní ochranu.

Jako zástupce malírské techniky na papíre byla pro tuto práci vybrána technika akvarelu, která patř́ $\mathrm{k}$ jedné $\mathrm{z}$ nejstarších. Jedná se o techniku lazurních nánosů silně pojených vodových barev, jejichž pojivem je arabská guma nebo její kombinace s tragantem (u levných výrobků to bývá i dextrin) [3]. Práce sleduje chování prripravených vzorků akvarelů v podmínkách umělého stárnutí, které se běžně používají v praxi při studiu degradace papíru. Cílem experimentu bylo nejen zjistit, jakým způsobem za zvolených podmínek umělého stárnutí probíhá degradace akvarelové vrstvy, ale také vyhodnotit do jaké míry se projeví její interakce s papírovou podložkou. 


\section{Stabilita studovaných pigmentů}

Pigmenty pro výrobu akvarelů byly voleny podle četnosti jejich využívání a předpokládané rozdílné citlivosti k vnějším vlivům. Šest sledovaných pigmentů zastupuje skupiny pigmentů různého původu - syntetické anorganické pigmenty a organické laky vyrobené z extraktů př́rodních organických materiálů.

Prvním z vybraných pigmentů byl francouzský okr (C. I. Pigment Yellow 43), jenž je považován za vysoce odolný pigment vůči vnějším vlivům. Jedná se o směs hydratovaného oxidu železa a hydroxidu železnatého. Odstín pigmentu závisí na obsahu oxidu železitého, jehož obsah se pohybuje u francouzského okru mezi 16 a $20 \%$ [4,5]. Nebezpečné je pro něj zahřívání nad $105^{\circ} \mathrm{C}$, při kterém ztrácí vodu a dochází ke změně jeho barvy [6]. Za běžných podmínek je velmi stabilní a okolní atmosféře odolává.

Dále byly pro testování vybrány dva modré pigmenty. Prvním byl syntetický ultramarín (C. I. Pigment Blue 29). Jedná se o stabilní pigment za všech běžných podmínek s chemickým složením $\mathrm{Na}_{7} \mathrm{Al}_{6} \mathrm{Si}_{6} \mathrm{O}_{24} \mathrm{~S}_{3}$. Nestabilní je pouze $\mathrm{v}$ kyselém prostředí stejně jako prŕrodní minerál lapis lazuli, z kterého se získává. Jeho struktura je založena na třídimenzionální aluminosilikátové mřížce s pevnou strukturou obsahující zachycené sodíkové ionty a iontové skupiny síry. Prrítomnost dvou typů skupin obsahujících síru $\mathrm{S}_{2}$ a $\mathrm{S}_{3}$ zajišt’uje absorpci v ultrafialovém a fialovém světle $\left(S_{2}\right)$ a zeleno-žlutooranžovém světle, díky čemuž je sloučenina modrá. Při teplotě nad $400{ }^{\circ} \mathrm{C}$ ztrácí ultramarín síru. V znečištěné atmosféře kyselými plyny může tento pigment degradovat a nenávratně vyblednout $[4,7]$.

Druhým modrým testovaným pigmentem byla pruská modř $\left(\mathrm{Fe}_{4}\left[\mathrm{Fe}(\mathrm{CN})_{6}\right]_{3}\right)$ (C. I. Pigment Blue 27), která patř́i $\mathrm{k}$ nejstarším moderním umělým pigmentům. Je odolná vůči zředěným kyselinám, ale obecně známá je její citlivost k př́tomnosti alkálií. Jejich vlivem se rozkládá za vzniku hnědého hydroxidu železitého. Také byl studován[8] vliv světla společně s nečistotami ovzduší na pruskou modř, díky kterým může dojít k její fotoredukci a změně barevnosti z modré na bílou. Tato reakce je v prítomnosti kyslíku reversibilní. Odolnost pigmentu vůči světlu klesá ve směsi s bílými pigmenty (nejvíce s oxidem zinečnatým) [8-10].

Ze zelených pigmentů byla vybrána měděnka (C. I. Pigment Green 20), která patří k velmi problematickým pigmentům způsobujícím korozi papírové či pergamenové podložky [11]. V závislosti na použité receptuře pro výrobu pigmentu se liší její chemické složení a fyzikální vlastnosti (barva, velikost a morfologie zrn). Obecně jsou hlavní složkou měděnky zásaditý acetát měd'natý $\mathrm{s}$ různým stupněm hydratace $\left(\mathrm{Cu}_{x}\left(\mathrm{CH}_{3} \mathrm{COO}\right)_{y} \cdot(\mathrm{OH})_{z} \cdot n \mathrm{H}_{2} \mathrm{O}\right)$, neutrální acetát měd'natý $\mathrm{S}$ různým stupněm hydratace $\left(\mathrm{Cu}\left(\mathrm{CH}_{3} \mathrm{COO}\right)_{2} \cdot n \mathrm{H}_{2} \mathrm{O}\right)$, nebo dokonce zásaditý chlorid měd’natý $\left(\mathrm{Cu}_{x} \mathrm{Cl}_{y} \cdot(\mathrm{OH})_{z}\right)$ doprovázené dalšími minoritními složkami [12-13]. Bylo prokázáno [11], že v papíru pod barevnou vrstvou s pigmentem měděnkou vzrůstá množství karbonylových skupin, zatímco v čistém papíru se tyto skupiny neobjevují. Zahříváním měděnky dochází $\mathrm{k}$ rozkladu octanu měd'natého na černý oxid mědi, vodu a kyselinu octovou [14]. Velmi chemicky aktivní je tzv. destilovaná měděnka, která se rozpouští ve vodě nebo v přírodních pryskyřicích za vzniku rezinátů mědi [15].

Poslední dva vybrané pigmenty byly zástupci organických laků. Prvním zástupcem bylo barvivo řešetlák, někdy známé také pod označením perské bobule. Jeho základní barvicí látkou je flavonoid rhamnetin (3,5,3`, $4^{6}$-tetrahydroxy-7-methoxyflavon), ale kromě něj mohou být $\mathrm{v}$ barvivu také prrítomny flavonoidy rhamnasin nebo kvercetin. Přesné složení barviva je vždy závislé na druhu rostliny použité $\mathrm{k}$ výrobě a zvolené receptuře. Žluté barvivo se získává z nezralých bobulí keřů rodu řešetlák (tj. přes 100 druhů keřù). Získaná štáva se extrahuje horkou vodou; získaný extrakt se sráží s roztokem $\mathrm{SnCl}_{4}$ na $\mathrm{Al}(\mathrm{OH})_{3}$ nebo na kamenec za vzniku organického laku. Ze zralých bobulí se získává řešetláková (tzv. št’avnatá) zeleň. Vylisovaná št'áva bobulí se sráží s kamencem a vinným kamenem $[5,16]$. Informace o stabilitě barviva nejsou v dostupné literatuře publikovány. Literatura $[5,16]$ pouze uvádí, že rhamnetin má nízkou stálobarevnost.

Druhým zástupcem organických laků bylo brazilské dřevo (C. I. Natural Red 24), jehož základními barvicími látkami jsou brazilin a brazilein. Barvivo má různé odstíny podle stupně oxidace brazilinu, kyselosti prostředí a volby substrátu. S postupující oxidací brazilinu získává barvivo stále hnědší odstín. Červený lak se připravuje srážením extraktu ze dřeva sapanu brazilského na inertní bázi (nejčastěji byl používán kamenec, ale také křída, mramorový prach, vaječné skořápky či olovnatá běloba) [5,16-17]. Z dostupných informací o stálosti tohoto organického laku je pouze publikováno [18-19], že brazilské dřevo je na světle málo stálé.

\section{EXPERIMENT}

\section{Příprava zkušebních vzorků}

Pro experiment byly zvoleny čtyři anorganické pigmenty s definovaným chemickým složením (viz Tab. 1) zakoupené od firmy Kremer Pigmente GmbH\& Co.: francouzský okr, ultramarín, pruská modř a měděnka. Dále byli k testování vybráni dva zástupci organických laků - brazilské dřevo a řešetlák, které byly připraveny laboratorně ze zakoupeného extraktu brazilského dřeva (Kremer, 36160) a sušených bobulí řešetláku počistivého (Kremer, 37380) od stejné firmy. Organický pigment brazilské dřevo byl připraven ze zakoupeného extraktu brazilského dřeva, který byl rozpuštěn v demineralizované vodě, povařen a následně vysrážen roztokem 
$\mathrm{K}_{2} \mathrm{CO}_{3}$ na kamenec $\left(\mathrm{KAl}\left(\mathrm{SO}_{4}\right)_{2} \cdot 12 \mathrm{H}_{2} \mathrm{O}\right)$. Organický lak řešetlák byl připraven ze sušených bobulí řešetláku počistivého, které byly 24 hodin macerovány. Získaný výluh byl taktéž povařen a následně vysrážen roztokem $\mathrm{K}_{2} \mathrm{CO}_{3}$ na kamenec $\left(\mathrm{KAl}\left(\mathrm{SO}_{4}\right)_{2} \cdot 12 \mathrm{H}_{2} \mathrm{O}\right)$.

Stabilita akvarelových barev prripravených z výše uvedených pigmentů byla testována na dvou druzích papírů lišících se svojí stabilitou. Charakteristiky použitých papírů uvádí Tab. 2.

Studované akvarelové barvy byly připraveny smícháním pigmentu, arabské gumy, etanolu a glycerolu dle publikované receptury [20]. Na $100 \mathrm{hm} . \%$ pigmentu

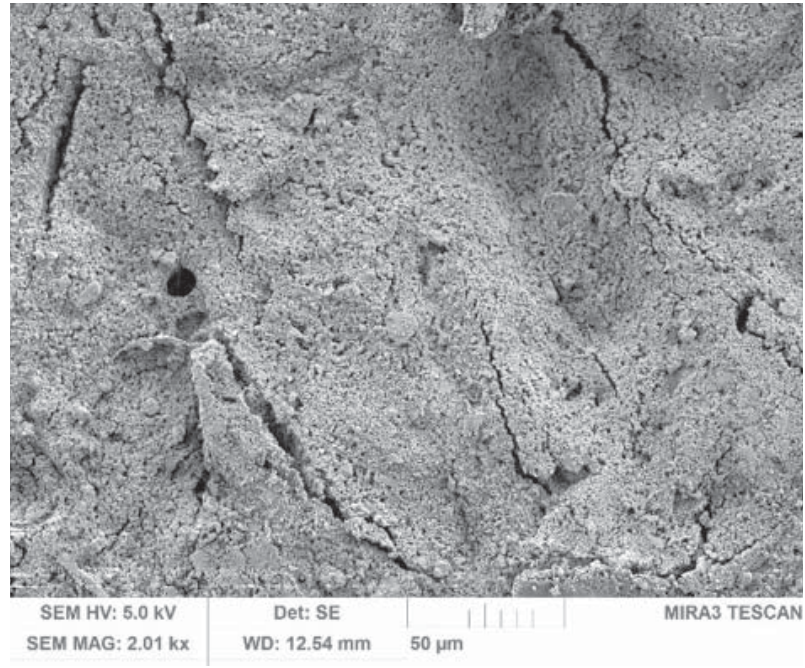

Obr. 1. Mikrostruktura povrchu akvarelu s pigmentem ultramarín na ručním papíre

Fig. 1. Microstructure of watercolor surface with ultramarine on cellulose paper
3-6 \% suchého pojiva $\mathrm{z}$ hmotnosti pigmentu ve formě $20 \%$ vodného roztoku, $1 \%$ absolutní etylalkohol z hmotnosti pigmentu a $1 \%$ glycerol $85 \% \mathrm{z}$ hmotnosti pigmentu. Připravené akvarelové barvy byly poté naředěny demineralizovanou vodou $\mathrm{v}$ poměru 2:1 tak, aby mohla být na papír nanesena automatickou nanášečkou Elcometer 4340 (Elcometer Inspection Equipment) vrstva akvarelu o tloušt'ce $20 \mu \mathrm{m}$.

Experimentálně bylo zjištěno, že i při použití $6 \%$ suchého pojiva $\mathrm{v}$ připraveném akvarelu uvedených $\mathrm{v}$ receptuře, dochází po nanesení vrstvy akvarelu k jejímu sprašování z papírové podložky. Z tohoto důvodu byl

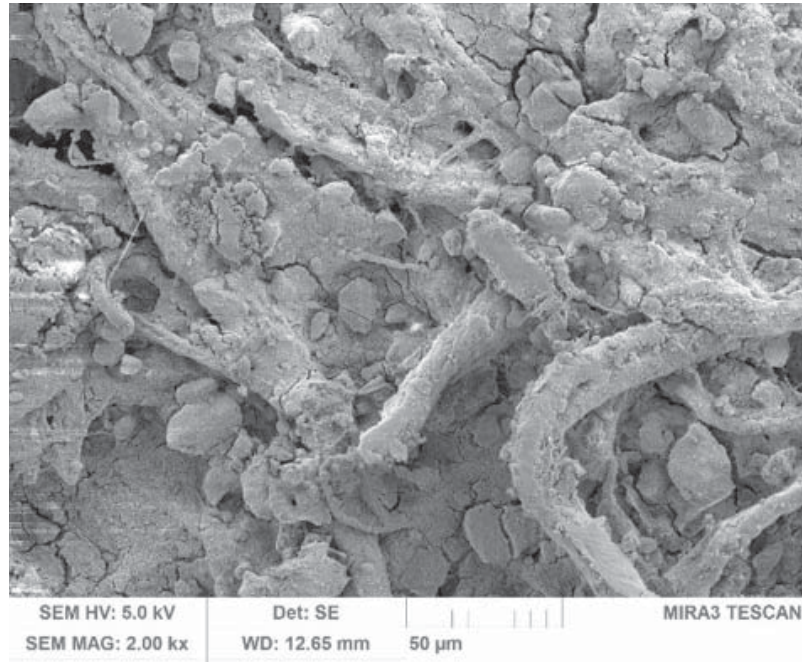

Obr. 2. Mikrostruktura povrchu akvarelu s pigmentem brazilské dřevo na ručním papíre

Fig. 2. Microstructure of watercolor surface with Brazilian wood on cellulose paper

Tab. 1. Charakteristika anorganických pigmentů použitých pro př́pravu zkušebních vzorků akvarelů / Characterization of inorganic pigments used with the designation for the preparation of watercolors samples

\begin{tabular}{|c|c|c|}
\hline Pigment & Referenční kód & Chemické složení dle dodavatele \\
\hline francouzský okr & 40070 & $\mathrm{Fe}_{2} \mathrm{O}_{3}, \mathrm{SiO}_{2}, \mathrm{Al}_{2} \mathrm{O}_{3}$ \\
\hline ultramarín & 45080 & $\mathrm{Na}_{8}\left[\mathrm{Al}_{6} \mathrm{Si}_{6} \mathrm{O}_{24}\right] \mathrm{S}_{4}$ \\
\hline pruská modř & 45202 & $\mathrm{Fe}(\mathrm{CN})_{6} \cdot \mathrm{Fe} \cdot \mathrm{NH}_{4}$ \\
\hline měděnka & 44450 & $\mathrm{C}_{4} \mathrm{H}_{6} \mathrm{CuO}_{4} \cdot \mathrm{H}_{2} \mathrm{O}, \mathrm{Cu}\left(\mathrm{CH}_{3} \mathrm{COO}\right)_{2} \cdot\left[\mathrm{Cu}(\mathrm{OH})_{2}\right]_{3} \cdot 2 \mathrm{H}_{2} \mathrm{O}$ \\
\hline
\end{tabular}

Tab. 2. Charakteristika papírových podložek použitých pro př́ípravu zkušebních vzorků / Characterization of papers used for preparing test samples

\begin{tabular}{|l|c|c|}
\hline Druh papírové podložky & Ruční papír & Dřevitý balicí papír \\
\hline Výrobce & papírna Velké Losiny & papírna Větřní \\
\hline Plošná hmotnost & $120 \mathrm{~g} \mathrm{~m}^{-2}$ & $60 \mathrm{~g} \mathrm{~m}^{-2}$ \\
\hline Hodnota pH vodného výluhu & 7,9 & 5,3 \\
\hline Složení papíru & $\begin{array}{c}60 \% \text { bavlna, } 40 \% \text { len, klížidlo - 2\% tech- } \\
\text { nická želatina s prídavkem 4 \% kamence } \\
\text { na hmotnost želatiny }\end{array}$ & $\begin{array}{c}26 \% \text { dřevovina, } 74 \% \text { nebělená sulfitová } \\
\text { buničina, } 6 \% \text { kaolin }\end{array}$ \\
\hline
\end{tabular}


obsah pojiva $v$ receptuře navýšen dle potřeby testovaných akvarelových barev lišících se velikostí zrn jednotlivých pigmentů (Obr. 1 a Obr. 2) tak, aby nanesená vrstva akvarelu se z papírové podložky nesprašovala. Výsledný poměr arabské gumy na $100 \mathrm{hm} . \%$ pigmentu byl $15 \mathrm{hm} . \%$ u ultramarinu a francouzského okru, $20 \mathrm{hm} . \%$ u brazilského dřeva a řešetláku a $25 \mathrm{hm} . \%$ u pruské modři a měděnky.

\section{Umělé stárnutí}

V experimentu byly vybrány tři nejčastěji používané modely umělého stárnutí použivané při studiu degradace papíru. Upravená metoda umělého stárnutí v podmínkách př́tomnosti $\mathrm{NO}_{2}$ dle ISO 5630/6 simulující prrítomnost škodlivin v ovzduší, umělé stárnutí vlhkým teplem podle ISO 5630/3 a modifikovaná metoda ISO 5630/1, která zastupuje termické stárnutí.

1. Umělé stárnutí $\mathrm{v}$ přítomnosti $\mathrm{NO}_{2}-$ Podmínky umělého stárnutí v prostředí $\mathrm{NO}_{2}$ definované normou ISO $5630 / 6$ byly upraveny. Koncentrace $\mathrm{NO}_{2}$ musela být snížena, aby nedošlo k poškození některých součástí komory, kde umělé stárnutí probíhalo. Připravené vzorky akvarelu byly vystaveny expozici $\mathrm{NO}_{2}$ o koncentraci 25 ppm při teplotě $23{ }^{\circ} \mathrm{C}$ a relativní vlhkosti prostředí $50 \%$. Umělé stárnutí probíhalo v klimatické komoře CTS (Magneton a.s.) po dobu 15 dní.

2. Umělé stárnutí vlhkým teplem - Vzorky akvarelu byly vystaveny expozici podmínkám dle ISO 5630/3, tzn. teplotě $80{ }^{\circ} \mathrm{C}$ a relativní vlhkosti prostředí $65 \%$. Umělé stárnutí probíhalo v klimatické komoře Sanyo HCC 019.CB1 (Sanyo Gallenkamp PLC) po dobu 33 dní.

3. Termické stárnutí - Metoda umělého stárnutí suchým teplem (dle ISO 5630/1) byla upravena snížením teploty ze $105{ }^{\circ} \mathrm{C}$ na teplotu $80{ }^{\circ} \mathrm{C}$ i za cenu výskytu zbytkové vlhkostí 5-7 \% v sušicí komoře. Pokud by byla při stárnutí použita teplota $105{ }^{\circ} \mathrm{C}$ uvedená v normě, lze předpokládat, že by pigmenty v akvarelu byly zbaveny krystalové vody. Umělé stárnutí probíhalo v sušicí komoře Sanyo OMT OVEN (Sanyo Gallenkamp PLC) po dobu 33 dní.

\section{Metody vyhodnocení}

Pro vyhodnocení vlivu umělého stárnutí na barevnou vrstvu akvarelů byla sledována celková barevná diference $\Delta E^{*}$ akvarelů vypočítaná ze vzorce [1]:

$$
\Delta E^{*}=\sqrt{\left(\Delta L^{*}\right)^{2}+\left(\Delta a^{*}\right)^{2}+\left(\Delta b^{*}\right)^{2}}
$$

Změny barevných koordinát $L^{*}, a^{*}, b^{*}$ barevného prostoru CIELab byly měřeny na přenosném spektrofotometru Minolta 2600-d (Konica) v režimu M/SCE a za podmínek UV 0 \%, D65, průměru měřené plochy
$8 \mathrm{~mm}$ a $2^{\circ}$ standardního pozorovatele. Dále byla studována reflexní spektra akvarelů měřená na UV-VIS spektrometru Unicam UV-500 s použitím integrační koule Labsphere (Thermo Spectronics) v rozsahu vlnových délek 266-734 nm.

$\mathrm{Z}$ důvodu objasnění pozorovaných barevných změn na uměle stárnutých vzorcích akvarelů byla proměřena změna povrchové hodnoty $\mathrm{pH}$ papíru z rubu vzorků. Hodnoty $\mathrm{pH}$ papírů byly měřeny na $\mathrm{pH}$ metru Orion Star A111 (Thermo Scientific) s kombinovanou elektrodou BlueLine 27 (SI Analytics GmbH).

Chemické změny $\mathrm{v}$ barevné vrstvě akvarelů po umělém stárnutí byly studovány pomocí metod instrumentální analýzy.

- Infračervená spektroskopie - Vzorky akvarelů byly studovány za pomoci ATR techniky na FTIR spektrometru Nicolet 380 (Thermo Scientific). Infračervená spektra byla měřena ve spektrálním rozsahu 4000-650 $\mathrm{cm}^{-1}$ při rozlišení $4 \mathrm{~cm}^{-1}$ a počtu akumulací spekter 128. Získaná spektra byla zpracována programem Omnic 7.1 (Nicolet Instruments Co., USA).

- Ramanova spektroskopie - Vzorky akvarelů byly měřeny pomocí Ramanova mikroskopu DXR Nicolet (Thermo Scientific) s měnitelnými lasery o vlnových délkách 532 a 780 nm. Spektra byla získávána za použití obou laserů (dle typu vzorku) při fokusaci excitačního záření na vzorek pomocí objektivu se zvětšením $50 \times$ nebo $100 \times$. Měření probíhalo po dobu $1 \times 300 \mathrm{~s}$ ( $\mathrm{v}$ případě pigmentu měděnky po umělém stárnutí také $1 \times 900 \mathrm{~s}$ nebo $1 \times 1800 \mathrm{~s}$ ) a spektra byla sbírána ve spektrálním rozsahu $50-3300 \mathrm{~cm}^{-1}$. Př́ístroj je standardně justován současně s kalibrací laserů pro přesnost vlnových délek a optimální intenzitu měřených spekter.

- Skenovací elektronová mikroskopie - Změny v morfologii zrn pigmentů akvarelů byly studovány na rastrovacím elektronovém mikroskopu Mira 3 LMU (Tescan) se Schottkyho autoemisní katodou. Vzorky akvarelů byly připevněny na hliníkový terč a pouhličeny. Mikrosnímky byly snímány se zvětšením 500× a $20000 \times$.

- Rentgenová difrakční analýza - Identifikace krystalických fází pigmentů a jejich degradačních produkti̊ byla stanovena na práškovém difraktometru Panalytical X'Pert Pro (PANalytical) v Bragg-Brentanově parafokusující geometrii $\mathrm{s}$ použitím vlnové délky $\mathrm{Cu} \mathrm{K} \alpha$ záření (1.5406 Å, $40 \mathrm{kV}, 30 \mathrm{~mA})$. Data byla naskenována pomocí ultrarychlého detektoru $\mathrm{X}^{`}$ Celerator v úhlovém rozsahu 5-60 $(2 \theta) \mathrm{s}$ krokem měření $0,02^{\circ}(2 \theta)$ a časem načítání 20 s/krok. Vyhodnocení dat bylo provedeno programem HighScore Plus 3.0. 
U vzorků neklíženého ručního papíru a akvarelů s pigmentem měděnkou vystavených podmínkám umělého stárnutí byl také vyhodnocen průměrný polymerační stupeň (PPS) celulózy. Jeho stanovení bylo provedeno $\mathrm{v}$ roztoku kadoxenu (ethylendiaminumonohydrátu o koncentaci 30 obj. \% s prrídavkem $\mathrm{CdO}$ ) pomocí Ubbelohdeho viskozimetru v temperované lázni při teplotě $25^{\circ} \mathrm{C}$ dle výpočtu [21]:

$$
P P S=193,5 *[\eta]^{1,064}
$$

kde $[\eta]$ je limitní viskozitní číslo.

\section{VÝSLEDKY A DISKUZE}

Po vystavení vzorků akvarelů podmínkám umělého stárnutí došlo $\mathrm{v}$ závislosti na použitém pigmentu barevné vrstvy akvarelu a typu papírové podložky ke změnám barevnosti - viz Obr. 3.

Celkové barevné diference $\Delta \mathrm{E}^{*}$ barevné vrstvy akvarelu po 15 dnech expozice podmínkám umělého stárnutí uvádí pro ruční papír Obr. 4 a pro dřevitý papír Obr. 5.

U samotných vzorků papíru byla mírně vyšší změna barevnosti zaznamenána $\mathrm{u}$ dřevitého papíru, která patrně souvisí se vznikem chinonových struktur $\mathrm{v}$ ligninu obsaženém $\mathrm{v}$ tomto papíru. $\mathrm{Na}$ výslednou změnu barevnosti po expozici všem použitým typům umělého stárnutí neměl ale typ papíru pozorovatelný vliv. Změny barevnosti vzorků akvarelů $\mathrm{s}$ pigmenty pruská modř $(\mathrm{P})$, ultramarín $(\mathrm{U})$ a francouzský okr $(\mathrm{O})$ nanesených na ručním i dřevitém papíre byly po expozici podmínkám umělého stárnutí srovnatelné se změnou barevnosti samotných papírů. Nejmenší změnu barevnosti vykazovala vždy barevná vrstva akvarelu s francouzským okrem. Vzhledem k dobré kryvosti tohoto pigmentu nebyla patrně výsledná barevnost akvarelu po umělém stárnutí výrazně ovlivňována změnou barevnosti papíru. Obecně lze dále konstatovat, že nejvýraznější změny barevnosti akvarelu na obou druzích papíru byly zaznamenány na vzorcích akvarelu $\mathrm{s}$ pigmentem měděnka $(\mathrm{M})$. Výrazné změny barevnosti byly pozorovány také na vzorcích akvarelu s organickými laky (B a R) umělé stárnutými $v$ atmosféře $\mathrm{NO}_{2}$. Takto výrazné barevné změny ( $\mathrm{u} \mathrm{M}, \mathrm{B}$ a $\mathrm{R}$ ) byly pozorovatelné již pouhým okem. Změny barevnosti vzorků akvarelu také znázorňují průběhy reflexních křivek jednotlivých barevných vrstev před a po expozici podmínkám umělého stárnutí. Obr. 6 znázorňuje srovnání reflexních křivek barevné vrstvy akvarelu s pigmentem měděnkou $(\mathrm{M}) \mathrm{v}$ různých podmínkách umělého stárnutí. Vrchol pásu měděnky, který se nachází při $498 \mathrm{~nm}$ se po umělém stárnutí $\mathrm{v} \mathrm{NO}_{2}$ posunul pouze minimálně (o $6 \mathrm{~nm}$ ). Pokles intenzity reflexní křivky je viditelný až po expozici akvarelu podmínkám termického stárnutí s posunem maxima vrcholu o $28 \mathrm{~nm}$. Po umělém stárnutí vlhkým teplem se maximum reflexní křivky měděnky ve vzorcích akvarelu úplně ztrácí, což odpovídá největší naměřené celkové barevné diferenci $\Delta \mathrm{E}^{*}$.
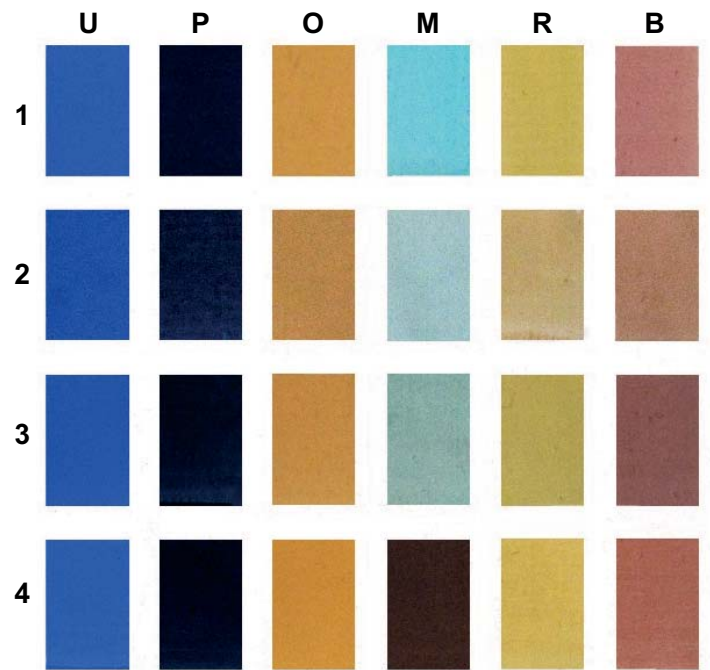

a)

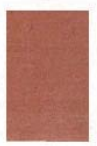

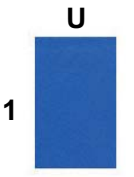
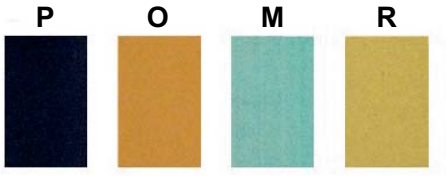

B

2
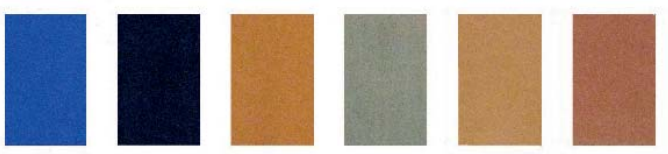

3
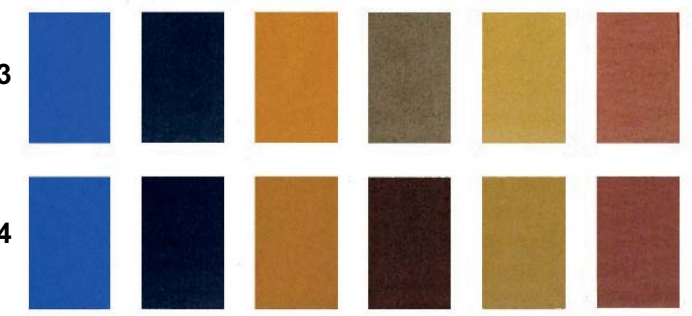

b)

Obr. 3. Srovnání vzorků po vystavení podmínkám umělého stárnutí (U - ultramarín, $\mathrm{P}$ - pruská modř, $\mathrm{O}$ - francouzský okr, M - měděnka, $\mathrm{R}$ - řešetlák, $\mathrm{B}$ - brazilské dřevo; 1 - standard, 2 - umělé stárnutí v $\mathrm{NO}_{2}, 3$ - termické stárnutí, 4 - umělé stárnutí vlhkým teplem)

Fig. 3. Comparison of the watercolor samples after exposure to artificial aging $(U$ - ultramarine, $P$ - Prussian blue, $O-F r e n c h$ ocher, $M$ - verdigris, $R$ - buckthorn, $B$ - Brazilian wood; 1 - standard, 2 - artificial aging with $\mathrm{NO}_{2}$, 3 - thermal aging, 4 - moist heat artificial aging) 


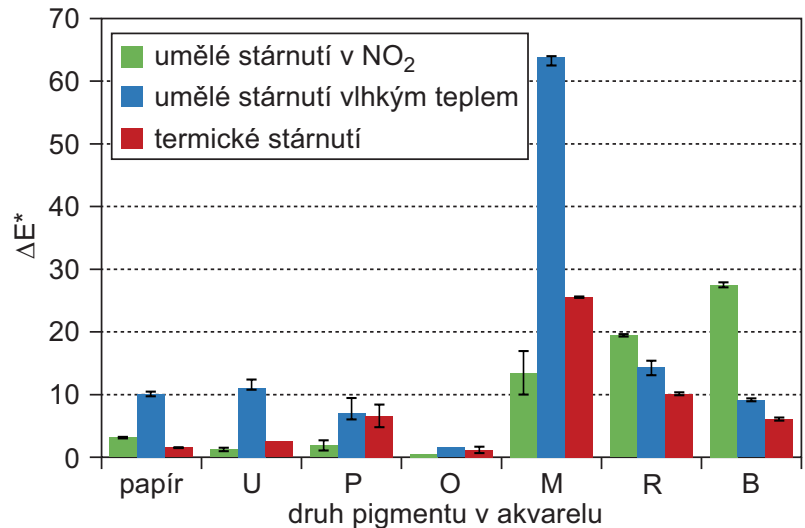

Obr. 4. Celková barevná diference barevné vrstvy akvarelu na ručním papíre $v$ závislosti na použitých podmínkách umělého stárnutí ( $U$ - ultramarín, $\mathrm{P}$ - pruská modř, $\mathrm{O}$ - francouzský okr, $\mathrm{M}$ - měděnka, $\mathrm{R}$ - řešetlák, $\mathrm{B}$ - brazilské dřevo) Fig. 4. Total color difference of watercolor paint layers on cellulose paper depending on artificial aging $(U-$ ultramarine, $P$ - Prussian blue, $O$ - French ocher, $M$ - verdigris, $R$ - buckthorn, $B$ - Brazilian wood)

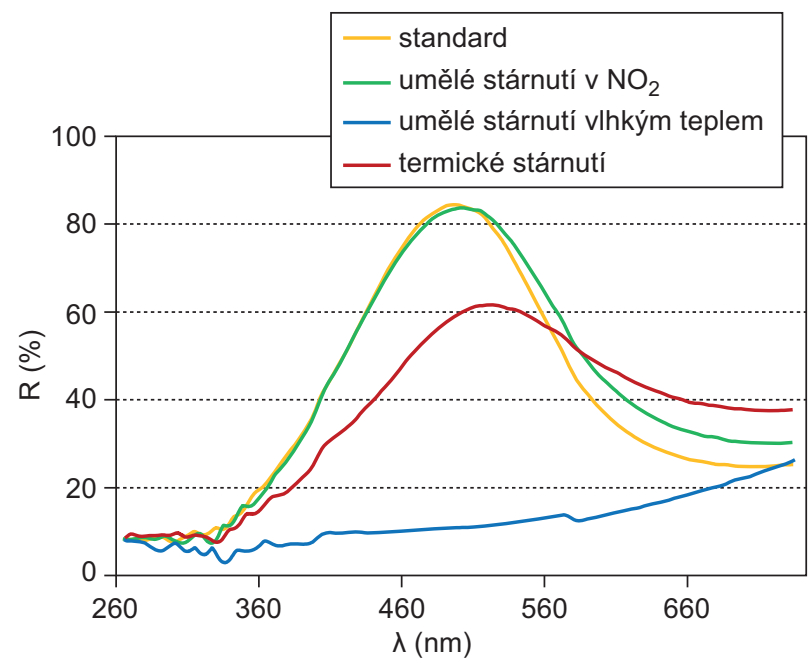

Obr. 6. Reflexní křivky barevné vrstvy akvarelu s pigmentem měděnka na ručním papíre

Fig. 6. Reflective curves of watercolor paint layers with verdigris on cellulose paper

Obr. 7 znázorňuje srovnání reflexních křivek barevné vrstvy akvarelu s pigmentem brazilské dřevo, jako vybraného zástupce organických laků. $\mathrm{V}$ tomto př́ípadě nebylo $\mathrm{v}$ proměřované oblasti reflexní křivky dosaženo maxima. Ze srovnání je tedy pouze patrný nárůst intenzity reflexní křivky po expozici vzorků umělému stárnutí suchým teplem a $\mathrm{v}$ přítomnosti $\mathrm{NO}_{2}$.

V průběhu expozice podmínkám umělého stárnutí došlo u všech papírů a studovaných vzorků akvarelů také ke změně hodnot $\mathrm{pH}$ papírů měřených $\mathrm{z}$ rubové strany barevné vrstvy akvarelů - viz Tab. 3. Největší změny hodnot $\mathrm{pH}$ byly naměřeny na vzorcích papíru

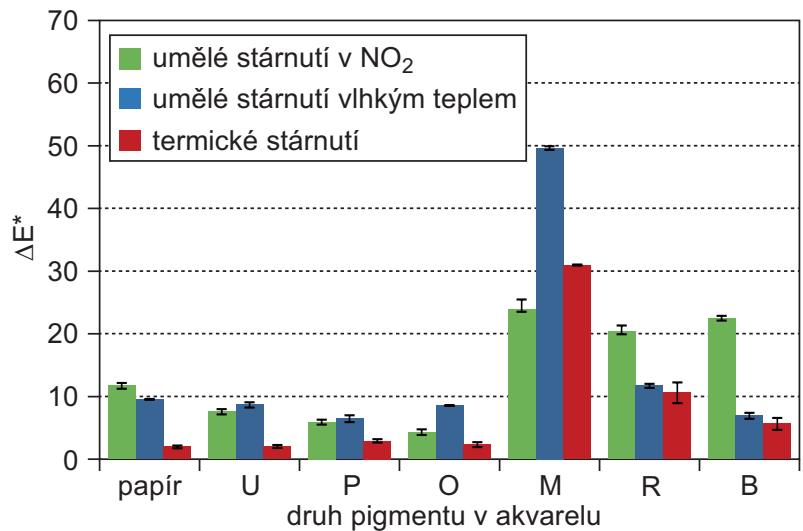

Obr. 5. Celková barevná diference barevné vrstvy akvarelu na dřevitém papíre v závislosti na použitých podmínkách umělého stárnutí ( $\mathrm{U}$ - ultramarín, $\mathrm{P}$ - pruská modř, $\mathrm{O}$ - francouzský okr, $\mathrm{M}$ - měděnka, $\mathrm{R}$ - řešetlák, $\mathrm{B}$ - brazilské dřevo) Fig. 5. Total color difference of watercolor paint layers on wood pulp based paper depending on artificial aging $(U$ - ultramarine, $P$ - Prussian blue, $O$ - French ocher, $M$-verdigris, $R$ - buckthorn, $B$-Brazilian wood).

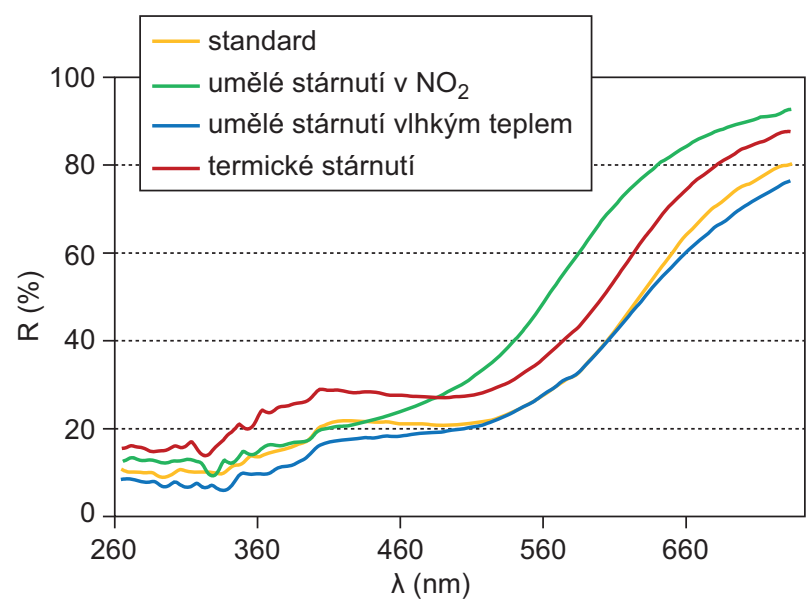

Obr. 7. Reflexní křivky barevné vrstvy akvarelu s pigmentem brazilské dřevo na ručním papíre

Fig. 7. Reflective curves of watercolor paint layers with Brazilian wood on cellulose paper

akvarelů po umělém stárnutí $\mathrm{v}$ atmosfére $\mathrm{s} \mathrm{NO}_{2}$, kde patrně došlo v papíru ke vzniku kyselých degradačních produktů. Ze získaných hodnot vyplývá, že složení papíru významně neovlivnilo hodnoty $\mathrm{pH}$ papírů po expozici podmínkám umělého stárnutí. Změny hodnot pH papíru v průběhu umělého stárnutí tedy nejsou hlavní př́činou zaznamenané změny barevnosti barevné vrstvy akvarelu.

Po expozici podmínkám umělého stárnutí nebyly pozorovány žádné změny v infračervených spektrech testovaných barevných vrstev vzorků akvarelu s pruskou modří, ultramarínem a francouzským okrem. V infra- 
červených spektrech vzorků akvarelů s organickými laky (brazilské dřevo a řešetlák) byl na obou typech studovaného papíru po vystavení podmínkám umělého stárnutí $\mathrm{v}$ atmosfére $\mathrm{NO}_{2}$ detekován nárůst dvou absorpčních pásů $\mathrm{S}$ vrcholy v pozicích kolem $1410 \mathrm{a} 1340 \mathrm{~cm}^{-1}$. Dle srovnání s literaturou [22,23] se pravděpodobně jedná o absorpční pásy př́slušící dusičnanům vzniklým ve struktuře těchto barevných vrstev. Přítomnost dusičnanů u těchto akvarelů se nepodařilo ve struktuře prokázat rentgenovou difrakční analýzou, nebot' se pravděpodobně nejedná o krystalické fáze. $V$ některých případech nemusí mít degradační produkty dobře vyvinutou krystalovou strukturu a spektra získaná rentgenovou difrakcí nemusí být pro identifikaci dostatečná. $\mathrm{V}$ takových př́padech je velmi užitečná informace získaná z FTIR spektroskopie, kterou lze charakterizovat aniony nebo chemické skupiny, a to i tehdy, není-li možné stanovit přesné složení sloučeniny, které tyto skupiny př́sluší [24]. Tyto detekované degradační produkty mohou být príćcinnou změny barevnosti barevných vrstev akvarelu zaznamenaných právě u akvarelu $\mathrm{s}$ těmito organickými pigmenty. Obr. 8 uvádí srovnání ATR-FTIR spekter barevné vrstvy akvarelu s pigmentem řešetlák na ručním papíru po expozici použitým podmínkám umělého stárnutí. Experimentálním zjištěním bylo také vyloučeno, že by vzniklé dva absorpční pásy pozorované v infračervených spektrech vzorků akvarelů $\mathrm{s}$ organickými laky po umělém stárnutí $\mathrm{v}$ atmosféře $\mathrm{s} \mathrm{NO}_{2}$ pocházely z degradačních produktů arabské gumy, jak dokazuje Obr. 9 .

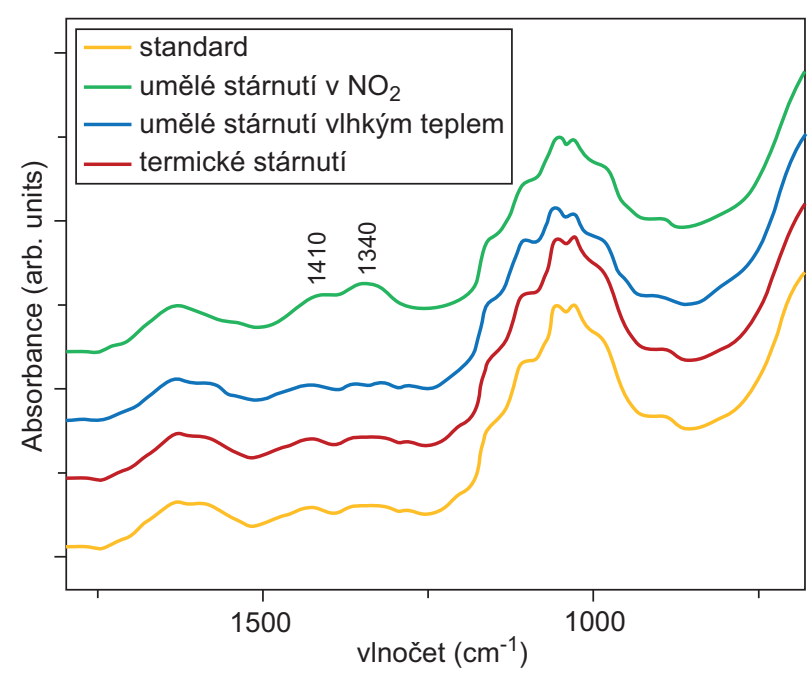

Obr. 8. Srovnání ATR-FTIR spekter barevné vrstvy akvarelu s pigmentem řešetlák po expozici podmínkám umělého stárnutí

Fig. 8. Comparison of ATR-FTIR spectra of watercolor paint layers with buckthorn after exposure to artificial aging (1 - standard, 2 - thermal aging, 3 - moist heat artificial aging, 4 - artificial aging with $\mathrm{NO}_{2}$ )

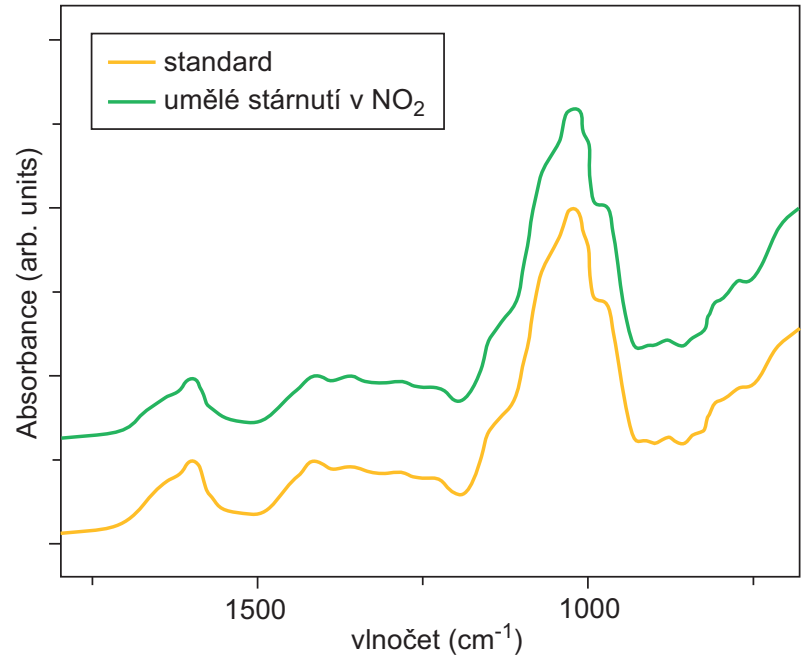

Obr. 9. Srovnání ATR-FTIR spekter arabské gumy po expozici podmínkám umělého stárnutí

Fig. 9. Comparison of ATR-FTIR spectra of Arabic gum after exposure to artificial aging (1 - standard, 2 - artificial aging with $\mathrm{NO}_{2}$ )

Tab. 3. Průměrné hodnoty $\mathrm{pH}$ rubu papíru s barevnou vrstvou akvarelu v závislosti na použitém druhu papírové podložky a expozici podmínkám umělého stárnutí (U - ultramarín, $\mathrm{P}$ - pruská modř, $\mathrm{O}$ - francouzský okr, $\mathrm{M}$ - měděnka, $\mathrm{R}$ - řešetlák, B - brazilské dřevo), maximální směrodatná odchylka měření byla $\pm 0,2$ / The average $p H$ values of paper with watercolor paint layers depending on the type of paper and exposure to artificial aging ( $U$-ultramarine, $P$ - Prussian blue, $O$ - French ocher, $M$ - verdigris, $R$-buckthorn, $B$-Brazilian wood), the maximum standard deviation were $\pm 0,2$

\begin{tabular}{|c|c|c|c|c|c|c|c|c|}
\hline \multirow{2}{*}{$\begin{array}{l}\text { Pigment } \\
\text { akvarelu }\end{array}$} & \multicolumn{2}{|c|}{ Standard } & \multicolumn{2}{|c|}{ Umělé stárnutí v $\mathrm{NO}_{2}$} & \multicolumn{2}{|c|}{$\begin{array}{c}\text { Umělé stárnutí vlhkým } \\
\text { teplem }\end{array}$} & \multicolumn{2}{|c|}{ Termické stárnutí } \\
\hline & $\begin{array}{l}\text { ruční } \\
\text { papír }\end{array}$ & $\begin{array}{l}\text { dřevitý } \\
\text { papír }\end{array}$ & $\begin{array}{l}\text { ruční } \\
\text { papír }\end{array}$ & $\begin{array}{l}\text { dřevitý } \\
\text { papír }\end{array}$ & $\begin{array}{l}\text { ruční } \\
\text { papír }\end{array}$ & $\begin{array}{l}\text { dřevitý } \\
\text { papír }\end{array}$ & $\begin{array}{l}\text { ruční } \\
\text { papír }\end{array}$ & $\begin{array}{l}\text { dřevitý } \\
\text { papír }\end{array}$ \\
\hline $\mathrm{U}$ & 5,0 & 3,5 & 3,0 & 1,8 & 3,6 & 4,2 & 4,6 & 3,1 \\
\hline $\mathrm{P}$ & 5,2 & 3,1 & 3,5 & 1,3 & 4,8 & 2,7 & 4,3 & 2,6 \\
\hline $\mathrm{O}$ & 4,8 & 2,6 & 2,7 & 0,4 & 4,3 & 1,7 & 4,4 & 2,3 \\
\hline M & 4,9 & 2,6 & 1,4 & 2,6 & 4,4 & 2,5 & 4,5 & 2,6 \\
\hline$\check{\mathrm{R}}$ & 4,5 & 3,0 & 2,3 & 1,2 & 3,8 & 3,1 & 3,7 & 2,7 \\
\hline $\mathrm{B}$ & 3,9 & 3,0 & 1,1 & 1,1 & 3,5 & 2,9 & 3,7 & 2,7 \\
\hline
\end{tabular}


Významné změny ve struktuře barevné vrstvy akvarelů byly pozorovány $\mathrm{v}$ infračervených a Ramanových spektrech uměle stárnutých vzorků s pigmentem měděnka. Tab. 4 shrnuje polohy absorpčních pásů naměřených ATR-FTIR spekter těchto vzorků $s$ jejich pravděpodobnou interpretací. Charakteristické absorpční pásy měděnky a jejích degradačních produktů se zde kombinují s pásy arabské gumy. Obr. 10 znázorňuje detail spektrální oblasti naměřených ATR-FTIR spekter $v$ rozsahu $500-2000 \mathrm{~cm}^{-1} \mathrm{~s}$ vyznačením charakteristických pásů popisující změny $\mathrm{v}$ chemickém složení měděnky. Polohy detekovaných pásů naměřených Ramanových spekter vzorků akvarelů s měděnkou, kde jsou uvedena maxima jednotlivých pásů $\mathrm{s}$ jejich pravděpodobnou interpretací, shrnuje Tab. 5.

Expozicí podmínkám umělého stárnutí při teplotě $80^{\circ} \mathrm{C}$ (tj. při umělém stárnutí vlhkým teplem a termickém stárnutí) došlo ve studovaných infračervených spektrech vzorků akvarelů s měděnkou $\mathrm{k}$ vymizení absorpčních pásů $\mathrm{s}$ vrcholy $\mathrm{v}$ pozicích $3500-3350 \mathrm{~cm}^{-1}$, které odpovídají valenční vibraci -OH skupiny z krystalické vody měděnky. V naměřených infračervených spektrech vzorků akvarelů vystavených podmínkám umělého stárnutí $\mathrm{v}$ př́tomnosti $\mathrm{NO}_{2}$ a vlhkého tepla nedošlo $\mathrm{k}$ vymizení charakteristických pásů zásaditého octanu, tj. výrazných absorpčních pásů v pozicích kolem 1600 , 1420 a $685 \mathrm{~cm}^{-1}$. U uměle stárnutých vzorků v atmosféře $\mathrm{NO}_{2}$ byl detekován významný nárůst absorpčního pásu $\mathrm{s}$ vrcholem $\mathrm{v}$ pozici $1321 \mathrm{~cm}^{-1}$ př́slušící degradačnímu produktu měděnky $\mathrm{v}$ akvarelu. Ten byl $\mathrm{v}$ Ramanových spektrech (pásy s vrcholy o vlnové délce 1048, 712, 505, 458 a $410 \mathrm{~cm}^{-1}$ - viz Obr. 11) detekován jako zásaditý dusičnan mědi. $\mathrm{V}$ těchto vzorcích byla ale patrná nerovnoměrná přeměna měděnky na dusičnan mědi, kdy

Tab. 4. Srovnání naměřených hodnot poloh FTIR absorpčních pásů akvarelu s měděnkou a akvarelů s degradačními produkty měděnky po umělém stárnutí s pravděpodobným přiřazením vibrací ( $\mathrm{w}$ - slabá intenzita, $\mathrm{m}$ - střední intenzita, $\mathrm{s}$ - vysoká intenzita; $v$ - valenční vibrace, $\delta$ - deformační vibrace) / Comparison of the measured values of FTIR absorption bands positions of watercolors samples with verdigris and degradation products after artificial aging with the probable vibrations assignment $(w-w e a k$ intensity, $m$ - medium intensity, $s$-strong intensity; $v$ - stretching vibration, $\delta$ - bending vibrations)

\begin{tabular}{|c|c|c|c|c|c|}
\hline Standard & $\begin{array}{c}\text { Umělé stárnutí } \\
\mathrm{v} \mathrm{NO}_{2}\end{array}$ & $\begin{array}{l}\text { Umělé stárnutí } \\
\text { vlhkým teplem }\end{array}$ & $\begin{array}{l}\text { Termické } \\
\text { stárnutí }\end{array}$ & Zdroj & $\begin{array}{c}\text { Pravděpodobné přiřazení } \\
\text { vibrace }\end{array}$ \\
\hline $3476 \mathrm{~m}$ & & & & pigment & $v(\mathrm{OH})[25-29]$ \\
\hline \multirow[t]{2}{*}{$3366 \mathrm{~m}$} & $3370 \mathrm{~m}$ & & & pigment & $v(\mathrm{OH})[25-26,28-29]$ \\
\hline & & $3333 \mathrm{~m}$ & $3334 \mathrm{~m}$ & pojivo & $v(\mathrm{OH})[25-26]$ \\
\hline $3270 \mathrm{~m}$ & $3270 w$ & & & pojivo, pigment & $v(\mathrm{OH})[25-26,28]$ \\
\hline \multirow[t]{3}{*}{$2915 \mathrm{w}$} & $2924 \mathrm{w}$ & $2921 \mathrm{w}$ & $2920 \mathrm{w}$ & pojivo, pigment & $v_{a}(\mathrm{CH})$ v CH $\mathrm{CH}_{3}[25,29]$ \\
\hline & $2855 \mathrm{w}$ & $2856 \mathrm{w}$ & $2854 \mathrm{w}$ & pojivo & $v_{a}(\mathrm{CH}) \vee \mathrm{CH}_{2}[27,29]$ \\
\hline & & $1660 \mathrm{~m}$ & & degr. produkt ${ }^{1}$ & $\delta(\mathrm{OH})[29]$ \\
\hline $1593 \mathrm{~s}$ & $1588 \mathrm{~m}$ & $1599 \mathrm{~s}$ & & pigment/pojivo & $v_{\mathrm{as}}(\mathrm{COO})[12,25,27-28]$ \\
\hline $1557 \mathrm{~m}$ & $1557 \mathrm{~m}$ & $1557 \mathrm{~s}$ & $1552 \mathrm{~s}$ & pigment/pojivo & $\mathrm{v}_{\mathrm{as}}(\mathrm{COO})[12]$ \\
\hline $1440 \mathrm{~s}$ & & & & pigment & $\delta_{\mathrm{as}}(\mathrm{CH}) \mathrm{v} \mathrm{CH}_{3}[2,12,25,27-28]$ \\
\hline \multirow[t]{2}{*}{$1420 \mathrm{~s}$} & $1418 \mathrm{~s}$ & $1411 \mathrm{~m}$ & $1423 \mathrm{~m}$ & pigment/pojivo & $v_{\mathrm{s}}(\mathrm{COO})[2,12,25,27-28]$ \\
\hline & & $1370 \mathrm{~m}$ & $1368 \mathrm{~m}$ & pojivo & - \\
\hline \multirow[t]{4}{*}{$1352 \mathrm{~m}$} & & & & pigment & $\delta_{\mathrm{s}}(\mathrm{CH}) \vee \mathrm{CH}_{3}$ a $\mathrm{CH}_{2}[2,25,27-29]$ \\
\hline & & & $1337 \mathrm{w}$ & pojivo & - \\
\hline & $1321 \mathrm{~s}$ & & & degr. produkt ${ }^{1}$ & - \\
\hline & & $1317 \mathrm{w}$ & $1312 \mathrm{w}$ & pojivo & - \\
\hline $1203 \mathrm{w}$ & $1203 \mathrm{w}$ & $1203 \mathrm{w}$ & $1203 \mathrm{w}$ & pojivo & - \\
\hline $1159 \mathrm{w}$ & $1159 \mathrm{w}$ & $1158 \mathrm{w}$ & $1159 \mathrm{w}$ & pojivo & - \\
\hline $1105 \mathrm{~m}$ & $1105 \mathrm{~m}$ & $1106 \mathrm{~m}$ & $1105 \mathrm{~m}$ & pojivo & - \\
\hline $1052 \mathrm{~s}$ & $1052 \mathrm{~s}$ & $1054 \mathrm{~s}$ & $1053 \mathrm{~s}$ & pojivo & $v_{\text {as }}(\mathrm{CO}), \delta(\mathrm{CH}) \mathrm{v} \mathrm{CH}_{3}[25,28-29]$ \\
\hline \multirow[t]{2}{*}{$1030 \mathrm{~s}$} & $1030 \mathrm{~s}$ & $1030 \mathrm{~s}$ & $1028 \mathrm{~s}$ & pojivo & $v_{\mathrm{s}}(\mathrm{CO}), \delta(\mathrm{CH}) \mathrm{v} \mathrm{CH}_{3}[25,27-29]$ \\
\hline & & $800 \mathrm{~m}$ & & degr. produkt ${ }^{1}$ & $\delta(\mathrm{Cu}-\mathrm{OH})[27]$ \\
\hline \multirow[t]{2}{*}{$687 \mathrm{~s}$} & $682 \mathrm{~s}$ & & & pigment & $\delta_{\text {in-plane }}(\mathrm{COO})[2,25]$ \\
\hline & & & $666 \mathrm{~s}$ & degr. produkt ${ }^{1}$ & $v(\mathrm{CuO})[30]$ \\
\hline
\end{tabular}

${ }^{1}$ degradačni produkt pigmentu (degradation product of pigment) 
Tab. 5. Srovnání naměřených hodnot poloh Ramanových pásů akvarelu s měděnkou a akvarelů s degradačními produkty měděnky po umělém stárnutí s pravděpodobným přiřazením vibrací ( $\mathrm{w}$ - slabá intenzita, $\mathrm{m}$ - střední intenzita, $\mathrm{s}$ - vysoká intenzita; $v$ - valenční vibrace, $\delta$ - deformační vibrace, / Comparison of the measured values of Raman bands positions of watercolors samples with verdigris and degradation products after artificial aging with the probable vibrations assignment ( $w$ - weak intensity, $m-$ medium intensity, $s$-strong intensity; $v$ - stretching vibration, $\delta$ - bending vibrations).

\begin{tabular}{|c|c|c|c|c|c|}
\hline Standard & $\begin{array}{c}\text { Umělé stárnutí } \\
\mathrm{v} \mathrm{NO}_{2}\end{array}$ & $\begin{array}{l}\text { Umělé stárnutí } \\
\text { vlhkým teplem }\end{array}$ & $\begin{array}{l}\text { Termické } \\
\text { stárnutí }\end{array}$ & Zdroj & $\begin{array}{c}\text { Pravděpodobné } \\
\text { přiřazení vibrace }\end{array}$ \\
\hline $3023 \mathrm{w}$ & & & & pigment & $v\left(\mathrm{CH}_{3}\right)[25,31-32]$ \\
\hline $2982 \mathrm{w}$ & & & & pigment & $v\left(\mathrm{CH}_{3}\right)[25,31-32]$ \\
\hline \multirow[t]{4}{*}{$2937 \mathrm{~m}$} & & & $2932 \mathrm{w}^{4}$ & pigment & $v(\mathrm{CH})[25,31-32]$ \\
\hline & $2893 \mathrm{w}$ & $2876 \mathrm{w}$ & $2881 \mathrm{w}$ & degr. produkt ${ }^{1}$ & - \\
\hline & & $1599 \mathrm{w}$ & $1586 \mathrm{w}$ & degr. produkt ${ }^{1}$ & - \\
\hline & $1538 \mathrm{w}$ & & & degr. produkt ${ }^{2}$ & - \\
\hline \multirow[t]{2}{*}{$1446 \mathrm{w}$} & & & & pigment & $\delta\left(\mathrm{CH}_{3}\right)[25,31]$ \\
\hline & $1436 \mathrm{w}$ & & & degr. produkt ${ }^{2}$ & - \\
\hline $1435 \mathrm{w}$ & & & & pigment & $v_{s}(\mathrm{COO})[25,31]$ \\
\hline $1413 \mathrm{w}$ & & & & pigment & $\delta\left(\mathrm{CH}_{3}\right)[25,31]$ \\
\hline \multirow[t]{6}{*}{$1361 \mathrm{w}$} & & & & pigment & $\delta\left(\mathrm{CH}_{3}\right)[25,31]$ \\
\hline & $1323 \mathrm{w}$ & & & degr.produkt ${ }^{2}$ & - \\
\hline & $1214 \mathrm{w}$ & & & degr. produkt ${ }^{2}$ & - \\
\hline & & $1117 \mathrm{w}$ & & degr. produkt ${ }^{1}$ & - \\
\hline & $1100 \mathrm{w}$ & & $1095 \mathrm{w}$ & degr. produkt ${ }^{1}$ & - \\
\hline & $1049 \mathrm{~s}$ & & & degr. produkt $\left(\mathrm{Cu}_{2} \mathrm{NO}_{3}(\mathrm{OH})_{3}\right)$ & $v_{\mathrm{s}}\left(\mathrm{NO}_{3}\right)[33]$ \\
\hline \multirow[t]{2}{*}{$948 \mathrm{~s}$} & & & & pigment & $v(\mathrm{CC})[25-26,31-32]$ \\
\hline & $712 \mathrm{w}$ & & & degr. produkt $\left(\mathrm{Cu}_{2} \mathrm{NO}_{3}(\mathrm{OH})_{3}\right)$ & - \\
\hline $702 \mathrm{w}$ & & & & pigment & $\delta(\mathrm{OCO})[25,31]$ \\
\hline \multirow[t]{6}{*}{$684 \mathrm{w}$} & & & & pigment & $\delta(\mathrm{OCO})[25-26,31]$ \\
\hline & & $590 \mathrm{~m}$ & $577 \mathrm{~m}$ & degr. produkt ${ }^{3}\left(\mathrm{CuO}, \mathrm{Cu}_{2} \mathrm{O}\right)$ & $\mathrm{Cu}-\mathrm{O}[34-36]$ \\
\hline & $507 \mathrm{w}$ & & & degr. produkt $\left(\mathrm{Cu}_{2} \mathrm{NO}_{3}(\mathrm{OH})_{3}\right)$ & $v(\mathrm{Cu}-\mathrm{OH})[33]$ \\
\hline & $454 \mathrm{w}$ & & & degr. produkt $\left(\mathrm{Cu}_{2} \mathrm{NO}_{3}(\mathrm{OH})_{3}\right)$ & $v(\mathrm{Cu}-\mathrm{OH})[33]$ \\
\hline & $411 \mathrm{w}$ & & & degr. produkt $\left(\mathrm{Cu}_{2} \mathrm{NO}_{3}(\mathrm{OH})_{3}\right)$ & - \\
\hline & & $342 \mathrm{w}$ & & degr. produkt $(\mathrm{CuO})$ & $\mathrm{Cu}-\mathrm{O}[34-36]$ \\
\hline \multirow[t]{3}{*}{$321 \mathrm{~s}$} & & & & pigment & $v(\mathrm{Cu}-\mathrm{O})[25]$ \\
\hline & & $297 \mathrm{~m}$ & $297 \mathrm{~m}$ & degr. produkt $(\mathrm{CuO})$ & $\mathrm{Cu}-\mathrm{O}[34-36]$ \\
\hline & $257 \mathrm{w}$ & & & degr. produkt $\left(\mathrm{Cu}_{2} \mathrm{NO}_{3}(\mathrm{OH})_{3}\right)$ & - \\
\hline $252 \mathrm{w}$ & & & & pigment & $v(\mathrm{Cu}-\mathrm{O})[25]$ \\
\hline $232 \mathrm{w}$ & & & & pigment & $v(\mathrm{Cu}-\mathrm{O})[25]$ \\
\hline \multirow[t]{2}{*}{$181 \mathrm{w}$} & & & & pigment & - \\
\hline & $164 \mathrm{w}$ & & & degr. produkt $\left(\mathrm{Cu}_{2} \mathrm{NO}_{3}(\mathrm{OH})_{3}\right)$ & - \\
\hline $124 \mathrm{w}$ & & & & pigment & - \\
\hline \multirow[t]{2}{*}{$104 \mathrm{~m}$} & & & & pigment & - \\
\hline & & $92 \mathrm{~m}^{4}$ & & degr. produkt $\left(\mathrm{Cu}_{2} \mathrm{O}\right)$ & $\mathrm{Cu}_{2} \mathrm{O}[36]$ \\
\hline $63 \mathrm{w}$ & & & & pigment & - \\
\hline
\end{tabular}

${ }^{1}$ degradačni produkt pocházejici pravděpodobně z pojiva (degradation product of pigment coming probably from binder)

${ }_{2}^{2}$ neznámý pás, pravděpodobně degradačni produkt (unknown band, probably the degradation product)

${ }^{3}$ pás přrirazený oxidům médi, prestože se od pásů v literatuře mírně liši (band assigned to copper oxides, although the bands

in the literature differ slightly)

${ }^{4}$ pás detekovaný pouze u akvarelu na ručním papíre (band detected only in watercolor sample on cellulose paper) 
dochází u některých zrn pouze $\mathrm{k}$ částečné změně struktury (nacházíme zde jak pásy původního pigmentu, tak pásy degradačních produktů), zatímco u jiných zrn byl naměřen pouze zásaditý dusičnan mědi. Rentgenovou difrakcí však nebyl tento degradační produkt v akvarelu identifikován (viz Tab. 6), detekován byl pouze neutrální octan měd’natý. $\mathrm{K}$ této chemické přeměně zásaditého octanu na neutrální patrně došlo vlivem vzniku kyselých degradačních produktů v papíru reakcí $\mathrm{s} \mathrm{NO}_{2}$. Viskozitní

Tab. 6. Detekované krystalické fáze ve vzorcích akvarelu s měděnkou po expozici podmínkách umělých stárnutí metodou rentgenové difrakční analýzy / Detected crystalline phases in watercolor samples with verdigris after exposure to artificial aging by $X$-ray diffraction analysis

\begin{tabular}{|l|l|}
\hline Typ umělého stárnutí & Detekované krystalické fáze \\
\hline \multirow{3}{*}{ standard } & $\mathrm{CuO}$ \\
& $\mathrm{CuC}_{2} \mathrm{O}_{4} \cdot \mathrm{xH}_{2} \mathrm{O}$ \\
& $\mathrm{Cu}_{2}\left(\mathrm{CH}_{3} \mathrm{COO}\right)_{0.9} \cdot(\mathrm{OH})_{3.1} \cdot 0.7 \mathrm{H}_{2} \mathrm{O}$ \\
\hline umělé stárnutí v $\mathrm{NO}_{2}$ & $\mathrm{Cu}\left(\mathrm{CH}_{3} \mathrm{COO}\right)_{2} \cdot\left(\mathrm{H}_{2} \mathrm{O}\right)$ \\
\hline \multirow{3}{*}{ umělé stárnutí vlhkým } & $\left(\mathrm{Cu}_{2}\left(\mathrm{CH}_{3} \mathrm{COO}\right)_{0.9} \cdot(\mathrm{OH})_{3.1} \cdot 0.7 \mathrm{H}_{2} \mathrm{O}\right.$ \\
teplem & $\mathrm{Cu}(\mathrm{OH})_{2} \cdot \mathrm{H}_{2} \mathrm{O}$ \\
& $\mathrm{Cu} 2$ \\
\hline termické stárnutí & $\mathrm{Cu}$ \\
\hline
\end{tabular}

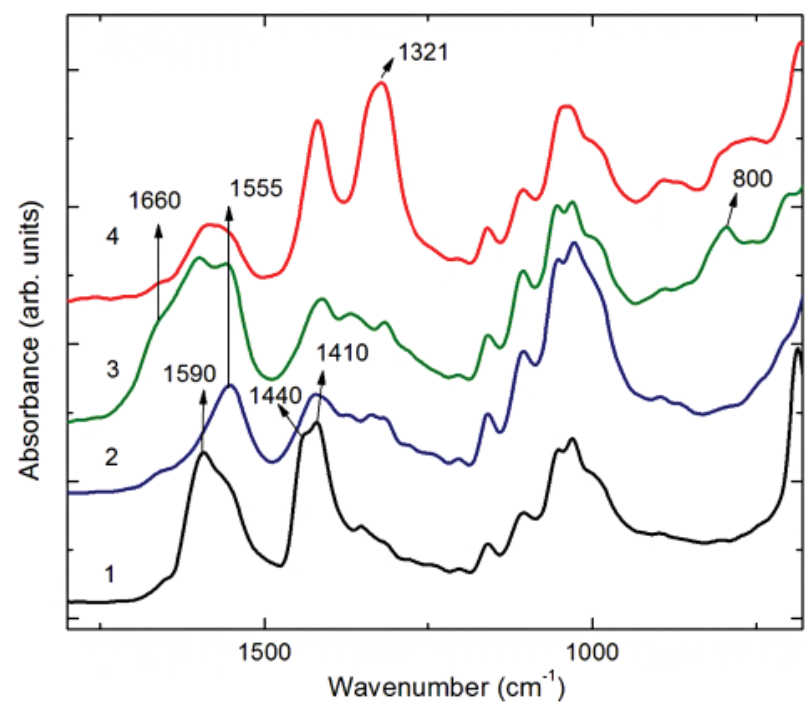

Obr. 10.Srovnání ATR-FTIR spekter barevné vrstvy akvarelu s pigmentem měděnka na ručním papíru po expozici podmínkám umělého stárnutí ( 1 - standard, 2 - termické stárnutí, 3 - umělé stárnutí vlhkým teplem, 4 - umělé stárnutí $\mathrm{s} \mathrm{NO}_{2}$ )

Fig. 10. Comparison of ATR-FTIR spectra of watercolor paint layers with verdigris on cellulose paper after exposure to artificial aging (1 - standard, 2 - thermal aging, 3 - moist heat artificial aging, 4 - artificial aging with $\mathrm{NO}_{2}$ ) metodou výpočtu PPS nebyl ale u tohoto vzorku akvarelu $\mathrm{s}$ měděnkou zaznamenán významný pokles průměrného polymeračního stupně celulózy.

Po umělém stárnutí vlhkým teplem byl v infračervených spektrech akvarelů $\mathrm{s}$ pigmentem měděnkou navíc detekován nárůst absorpčních pásů $\mathrm{s}$ vrcholy $\mathrm{v}$ pozicích 1660 a $800 \mathrm{~cm}^{-1}$ pravděpodobně související se vznikem vazby $\mathrm{Cu}-\mathrm{OH}$. Ramanovou spektroskopií byly u těchto vzorků detekovány především oxidy mědi, jak ukazuje Obr. 12. Detekovány byly pásy s vrcholy kolem vlnových délek $590 \mathrm{~cm}^{-1}, 345 \mathrm{~cm}^{-1}, 297 \mathrm{~cm}^{-1}$ a $92 \mathrm{~cm}^{-1}$, které náleží $\mathrm{CuO}$ a $\mathrm{Cu}_{2} \mathrm{O}$. Ramanův pás $\mathrm{s}$ vrcholem na $92 \mathrm{~cm}^{-1}$ byl detekován u vzorků akvarelů na ručním papíru a dle literatury [36] odpovídá sloučenině $\mathrm{Cu}_{2} \mathrm{O}$. Pás s vrcholem na $590 \mathrm{~cm}^{-1}$ se mírně liší od standardních spekter publikovaných $\mathrm{v}$ literatuře, $\mathrm{k}$ posunům pásů však může docházet např. v důsledku odlišné velikosti zrn [34]. Vzhledem k nižší kvalitě spekter, která byla způsobena citlivostí vzorků na oba typy excitačního záření po expozici podmínkám umělého stárnutí, je nutné přihlédnout také k šířce tohoto pásu a obtížnějšímu stanovení přesného maxima. Rentgenová difrakční analýza prokázala (viz Tab. 6), že vlivem umělého stárnutí vlhkým teplem došlo ve struktuře měděnky ke vzniku směsi zásaditého octanu měd'natého, hydratovaného hydroxidu mědnatého, oxidu měd'ného a práškové mědi. Identifikované tmavé degradační produkty mědi jsou tedy patrně prríčinnou velké změny barevnosti těchto vzorků. Průměrný polymerační stupeň celulózy u vzorků

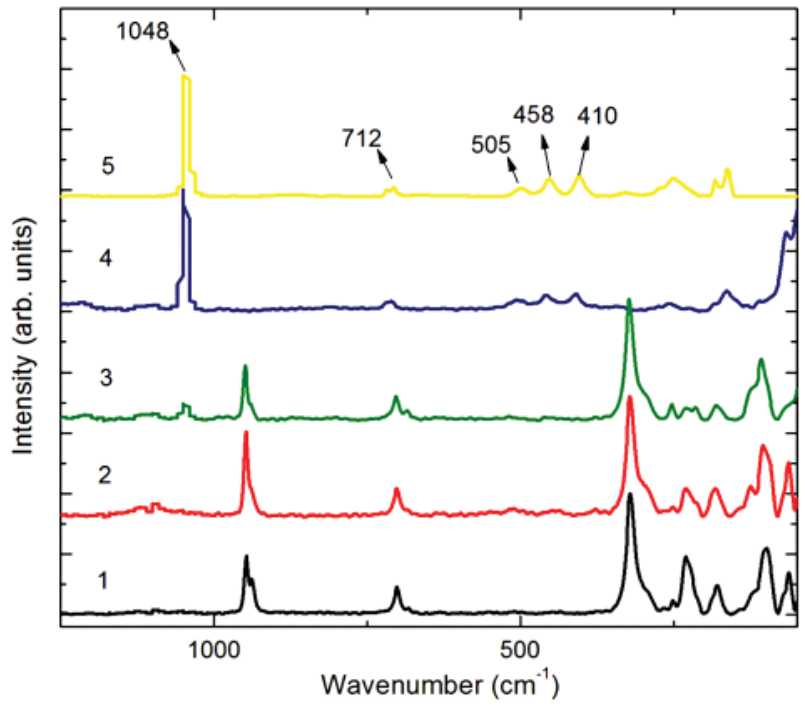

Obr. 11.Srovnání Ramanových spekter barevné vrstvy akvarelu s pigmentem měděnka na ručním papíru (1 - standard akvarelu před umělým stárnutím, 2-4 - umělé stárnutí $\mathrm{s}^{\mathrm{NO}_{2}}$, $\left.5-\mathrm{Cu}_{2}\left(\mathrm{NO}_{3}\right) \cdot(\mathrm{OH})_{3}\right)$

Fig. 11. Comparison of Raman spectra of watercolor paint layers with verdigris on cellulose paper (1 - watercolor standard before artificial ageing, 2-4 - artificial ageing with $\mathrm{NO}_{2}$, $\left.5-\mathrm{Cu}_{2}\left(\mathrm{NO}_{3}\right) \cdot(\mathrm{OH})_{3}\right)$ 
akvarelu s měděnkou uměle stárnutých vlhkým teplem poklesl z hodnoty $280 \pm 4$ na $105 \pm 1$. Takto výrazný pokles PPS více než o polovinu původní hodnoty vypovídá o výrazném degradačním účinku měděnky na ruční papír za použitých podmínek umělého stárnutí.

Po expozici podmínkám termického stárnutí zcela vymizely $\mathrm{v}$ infračerveném spektru akvarelu $\mathrm{s}$ pigmentem měděnkou absorpční pásy octanů a došlo zde $\mathrm{k}$ nárůstu výrazného pásu s vrcholem v pozici $666 \mathrm{~cm}^{-1}$

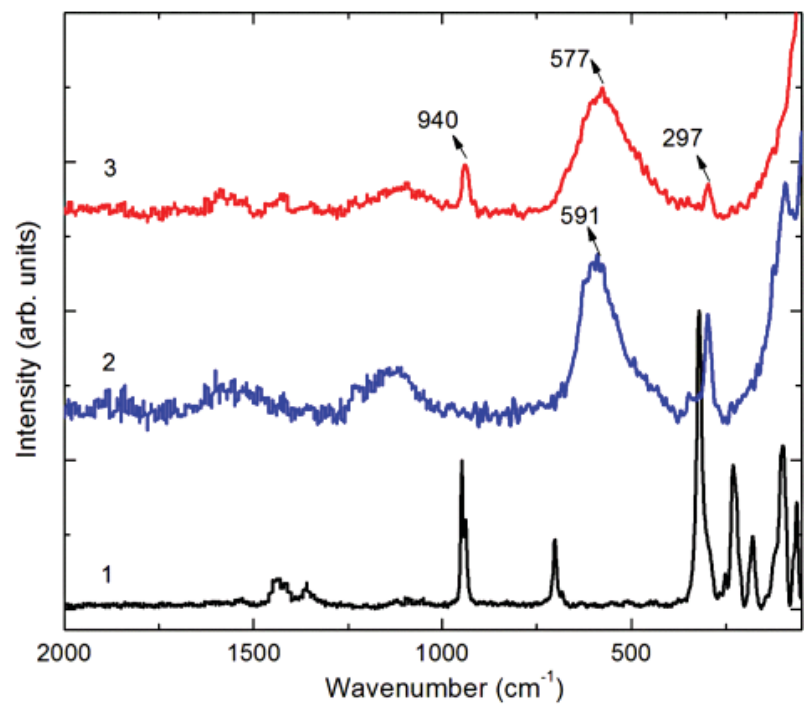

Obr. 12. Srovnání Ramanových spekter barevné vrstvy akvarelu s pigmentem měděnka na ručním papíru po expozic podmínkám umělého stárnutí (1 - standard, 2 - umělé stárnutí vlhkým teplem, 3 - termické stárnutí)

Fig. 12. Comparison of Raman spectra of watercolor paint layers with verdigris on cellulose paper after exposure to artificial aging (1 - standard, 2 - moist heat artificial aging, 3 - thermal aging)

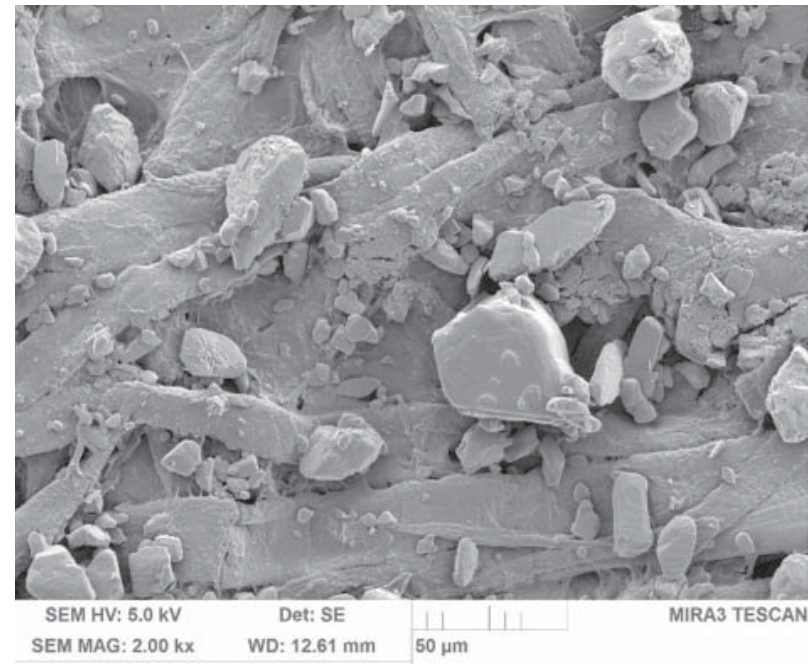

Obr. 13. Mikrostruktura povrchu akvarelu s pigmentem měděnka na ručním papíře

Fig. 13. Microstructure of watercolor surface with verdigris on cellulose paper příslušící valenční vibraci vazby $\mathrm{Cu}-\mathrm{O}$ [27] (viz Obr. 10). Stejný výsledek [34-36] byl potvrzen také Ramanovou spektroskopií (viz. Obr. 12). V Ramanově spektru vzorku akvarelu s pigmentem měděnka na ručním papíře byly detekovány také zbytky původního pigmentu v podobě slabého pásu s vlnočtem $940 \mathrm{~cm}^{-1}$. Oxid měd'natý byl detekován jako jediná krystalická fáze $\mathrm{v}$ těchto vzorcích akvarelů také rentgenovou difrakční analýzou (viz Tab. 6). I u termicky stárnutých vzorků akvarelů $\mathrm{s}$ měděnkou byl zaznamenán mírný pokles průměrného polymeračního stupně celulózy, konkrétně z hodnoty $491 \pm 5$ na $338 \pm 3$. Degradace vzorků akvarelů s pigmentem měděnka vystavených termickému stárnutí probíhala oproti vzorkům vystaveným podmínkám umělého stárnutí vlhkým teplem pomaleji, což se projevilo také jejich menší barevnou změnou.

Strukturální změny probíhající ve vzorcích akvarelů se významně neprojevily v morfologii povrchu barevné vrstvy u žádné kombinace studovaného pigmentu a papíru vyjma vzorků akvarelů s měděnkou (viz Obr. 13-16). Po umělém stárnutí vlhkým teplem se na povrchu akvarelu (Obr. 15) objevuje jemný práškový podíl patrně př́islušící práškové mědi.

\section{ZÁVĚR}

Z dosažených výsledků vyplývá, že vzorky akvarelů s pigmenty francouzský okr, pruská modř a ultramarín se projevily vůči testovaným podmínkám umělého stárnutí jako stálé. Experimentálně byl prokázán významný vliv atmosféry $\mathrm{NO}_{2}$ na vzorky akvarelů s organickými laky patrně související se vznikem kyselých degradačních produktů, které se projevily výraznou změnou barevnosti akvarelu. Další významné změny byly detekovány

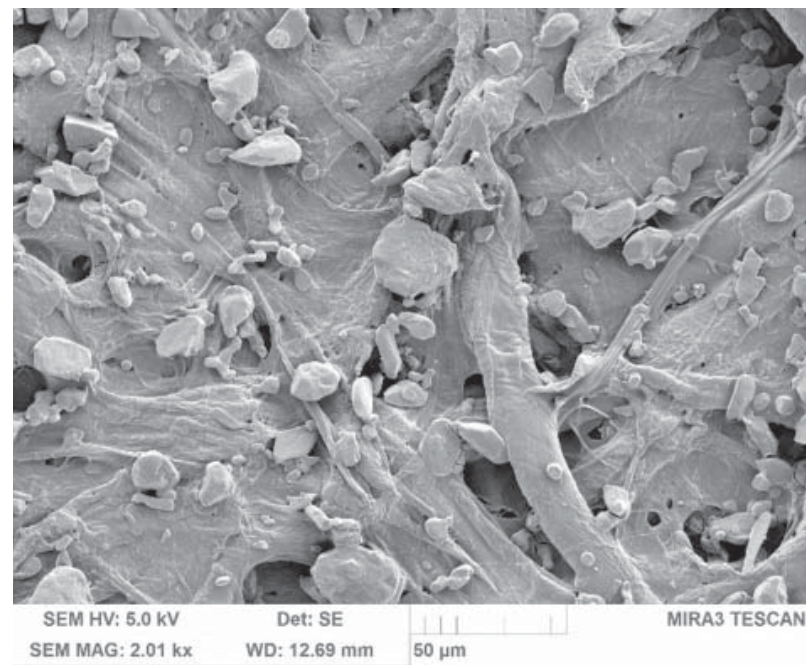

Obr. 14. Mikrostruktura povrchu akvarelu s pigmentem měděnka na ručním papíre po expozici atmosféře $\mathrm{s} \mathrm{NO}_{2}$

Fig. 14. Microstructure of watercolor surface with verdigris on cellulose paper after exposure to artificial aging with $\mathrm{NO}_{2}$ 


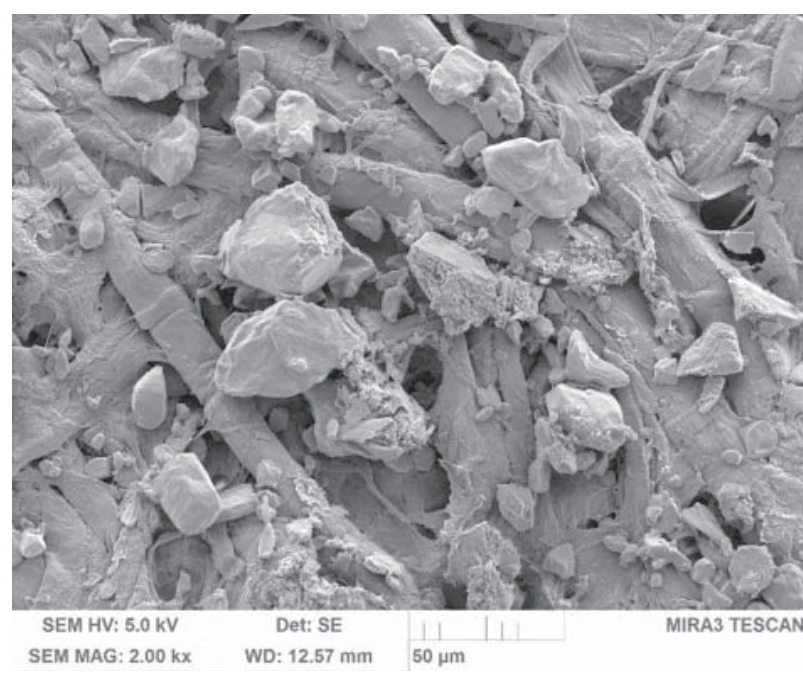

Obr. 15. Mikrostruktura povrchu akvarelu s pigmentem měděnka na ručním papíre po umělém stárnutí vlhkým teplem Fig. 15. Microstructure of watercolor surface with verdigris on cellulose paper after exposure to moist heat artificial aging

ve vzorcích akvarelů s měděnkou vůči všem testovaným podmínkám umělého stárnutí související se změnami v chemickém složení pigmentu. Barevná změna akvarelů vyvolaná umělým stárnutím byla tedy $\mathrm{v}$ př́ímé souvislosti se změnou chemického složení barevné vrstvy. Experimentálně nebyl také pozorován výrazný vliv studovaných papírů na stabilitu barevné vrstvy akvarelu za použitých podmínek umělého stárnutí, které nebyly patrně dostatečné $\mathrm{k}$ vyvolání oxidačních a hydrolytických reakcí v ligninu testovaného dřevitého balicího papíru.

Tato práce slouží jako výchozí studie pro navazující testování sledování vlivu konzervačních metod dezinfekce a odkyselování na barevné vrstvy akvarelů studovaných v rámci projektu VEPA - Věda pro papírové artefakty.

\section{Poděkování}

Výzkum byl spolufinancován z Evropského sociálního fondu a státního rozpočtu $\breve{C} R$ v rámci projektu VEPA - Věda pro papírové artefakty, reg. č. CZ.1.07/ 2.3.00/20.0236.

\section{LITERATURA}

1. Papliaka, Z. E., Wendland, N., Varella, E. A.: The Protective Role of Titanium Dioxide Pigments on Pictorial Artworks in Contaminated Indoor Environments. e-PS, 2010, 7, 4854.

2. Berkey, M., Shugar, A., Bartlett, K.: Effects of Aging Verdigris in Artist Prepared Paint. Poster, Buffalo State College, 2009, [2015-03-15]. URL: http://www.academia.

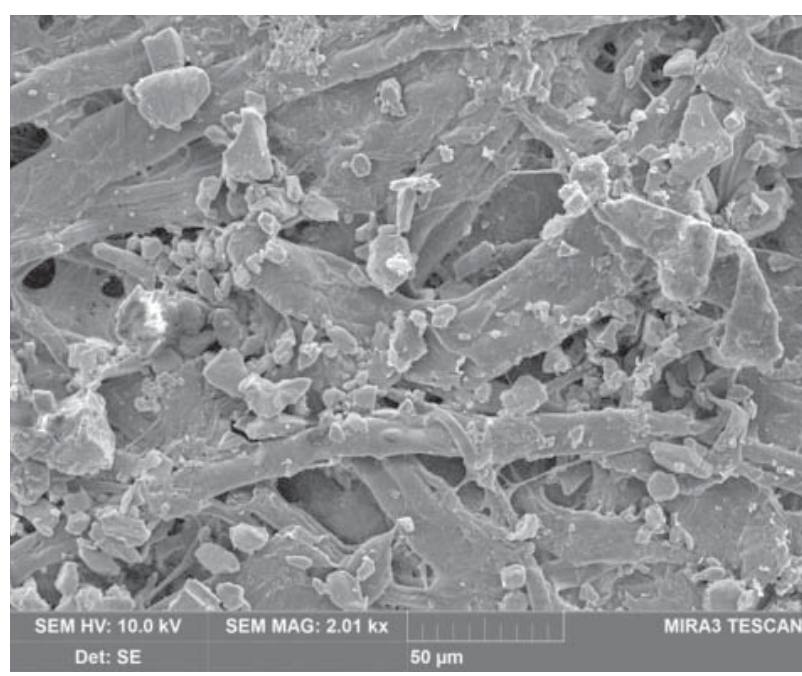

Obr. 16. Mikrostruktura povrchu akvarelu s pigmentem měděnka na ručním papíre po termickém stárnutí

Fig. 16. Microstructure of watercolor surface with verdigris on cellulose paper after exposure to thermal aging

edu/4281352/_2009_Effects_of_Aging_Verdigris_in Artist_Prepared_Paint_Berkey_Shugar_and_Bartlett_

3. Slánský, B.: Technika v malírské tvorbě. I. díl-malǐrský a restaurátorský materiál. SNTL, 1976, 223-224.

4. Eastaugh, N., Et Al.: Pigment Compendium: A Dictionary and Optical Microscopy of Historic. Elsevier, 2008.

5. Šimůnková, E.; Bayerová, T.: Pigmenty. STOP, 1999, 57-58.

6. Rutheford, G. J., Et Al.: Painting materials. A short encyclopedia. New York Dover Publication, 1966.

7. Plesters, J.: Ultramarine Blue, Natural and Artificial. Studies in Conservation, 1966,11 (2), 62-91.

8. Ware, M.: Prussian Blue: Artists' Pigment and Chemists' Sponge. Journal of Chemical Education, 2008, 85 (5), 612-621.

9. Samane, L., Et Al.: Fading of modern Prussian blue pigments in linseed oil medium. Journal of Analytical Atomic Spectrometry, 2011, 26, 930-941.

10. Kirby, J.; Saunders, D.: Fading and Colour Change of Prussian Blue: Methods of Manufacture and the Influence of Extenders. National Gallery Technical Bulletin, 2004, 25, 73-99.

11. Banik, G.: Naturwissenschaftliche Untersuchungen zur Aufklärung des Kupferfraßes in graphischen Kunstwerken. Das Papier, 1982, 36, 438-448.

12. Švarcová, S., Et. Al.: Non-destructive micro-analytical differentiation of copper pigments in paint layers of works of art using laboratory-based techniques. Spectrochimica Acta, 2014, 132 (A), 514-525.

13. De La Roja, J. M.; Baonza, V. G.; San Andrés, M.: Application of Raman microscopy to the characterization of different verdigris variants obtained using recipes from old treatises. Spectrochimica Acta, 2007, 68 (A), 1120-1125.

14. Kuhn, H: Verdigris and Copper Resinate. Artists' Pigmente. A Handbook of Their History and Characteristics, 1989, 2, 131-154. 
15. Mactaggart, P., Mactaggart, A.: A Pigment Microscopist's Notebook. $3^{\text {rd }}$ ed.,1998, 14-15.

16. Hofenk De Graaff, J. H.: The Colourful Past - Origins, Chemistry and Identification of Natural Dyestuffs. Archytape, 2004.

17. Čopíková, J., et. al.: Př́rodní barevné látky. Chemické listy, 2005, 99, $802-816$.

18. Saunders, D., Kirby, J.: Wavelengt Dependent Fading of Artist's Pigments. Preventive Conservation, Practice, Theory and Research. 1994, 190-194.

19. Saunders, D.: Light - induced Colour Changes in Red and Yellow Lake Pigments. National Gallery Technical Bulletin. 1994, 15, 79-97

20. Hegr, M.: Technika malírského umění. Umělecká Beseda v Praze, 1941, s. 58.

21. Milichovský, M., et al.: Návody pro laboratorní cvičeni z chemické technologie papiru a celulózy - I. část. VŠCHT v Pardubicích, 1979, s. 44.

22. Hashimoto, A., et al.: Simple, Rapid and Non-Destructive Determination of Nitrate Nitrogen Content Using MidInfrared Spectroscopic Method. In. IAALD AFITA WCCA 2008 - World Conference on Agricultural Information and IT. 2008, 235-240.

23. Socrates, G.: Infrared Characteristic Group Frequencies tables and charts. 3rd ed., 2001.

24. Scott, D. A.: Měd'a bronz vuméní: koroze, barviva, konzervace. Conservation. Getty Publications, 2002, [2015-04-16]. URL: http://www.sups.info/download/scott_med $\% 20 \mathrm{a} \% 20$ bronz_preklad.pdf

25. Conti, C., et al.: The detection of copper resinate pigment in works of art: contribution from Raman spectroscopy. $J$. Raman Spectrosc., 2014, 45, 1186-1196.

26. San Andrés, M., et al.: Verdigris pigment: a mixture of compounds. Input from Raman spectroscopy. J. Raman Spectrosc., 2010, 41, 1468-1476.
27. Zaffino, CH., et al.: Exploiting external reflection FTIR spectroscopy for the in-situ identification of pigments and binders in illuminated manuscripts. Brochantite and posnjakite as a case study. Spectrochimica Acta, 2015, 136 (A), 1076-1085.

28. Buti, D., et al.: In-situ identification of copper-based green pigments on paintings and manuscripts by reflection FTIR. Anal. Bioanal. Chem., 2013, 405, 2699-2711.

29. Derrick, M. R., Stulik, D., Landry, J. M.: Infrared spectroscopy in conservation science. The Getty Conservation Institute, 1999.

30. Johan, M. R., et al.:Annealing Effects on the Properties of Copper Oxide Thin Films Prepared by Chemical Deposition. Int. J. Electrochem. Sci., 2011,6, $6094-6104$.

31. Musumeci, A., Frost, R. L.: A spectroscopic and thermo analytical study of the mineral hoganite. Spectrochimica Acta, 2007, 67 (A), 48-57.

32. Musumeci, A., et al: A spectroscopic study of the mineral paceite (calcium acetate). Spectrochimica Acta, 2007, 67 (A), 649-661.

33. Frost, R. L., et al: Raman spectroscopy of likasite at 298 and 77K. Spectrochimica Acta, 2005, 61 (A), 607-612.

34. Xu, J. F., et al.: Raman Spectra of CuO Nanocrystal. Journal of Raman Spectroscopy, 1999, 30, 413-415.

35. Chou, M. H., et al: Confocal Raman spectroscopic mapping studies on a single $\mathrm{CuO}$ nanowire. Applied Surface Science, 2008, 254, 7539-7543.

36. Meyer, B. K., et al: Binary copper oxide semiconductors: From materials towards devices. Phys. Status Solidi B, 2012, 249 (8), 1487-1509. 